\title{
Motivation And Working Behavior In Frontier Tourism Business Of Thailand-Laos
}

Thirachaya Maneenetr, Khon Kaen University, Thailand

\begin{abstract}
The objectives of this research were to study the motivations and working behavior of the frontier tourism business at the Thailand-Laos border, to compare the working relationship between travel agencies and the hotel business, and to study the relationship between working motivation and working behavior in the tourism business by using a total sampling of 140 persons: 112 persons from the hotel business and 28 persons from travel agencies. Personnel in the tourism business consisted of $42.1 \%$ males and 57.9\% females. The ages ranged accordingly: 15-25 years old (15.0\%), 26-35 years old (53.6\%), and 36-45 years old (26.4\%). The educational levels of the sample group were: high school diploma or equivalent (28.6\%), associate's degree or equivalent (27.9\%) and bachelor's degree (27.9\%). Most of the personnel in the tourism business had a working motivation in the moderate range and the others were in the high range. Most of the personnel in the tourism business thought that their work quantities were in the moderate range. The overall work qualities were in the high range. Therefore, the personnel were considered to be worthy resources for having an average in the highest range. For overall abilities, they were in the high range and their average rating for morals was in the high range. The relationship with the organization of the personnel in the tourism business was in the moderate range; however, if someone criticized their organization, they would suddenly rise into the high range. In addition, the results of the hypotheses are: 1) the working behavior in the travel agencies and hotel business had the same significance rank of 0.05; 2) the working motivation of the personnel in travel agencies had a positive relationship with their working behavior having a significance rank of 0.05 by using the Pearson's Product Moment Correlation result of 0.69; 3) the working motivation of the personnel in the hotel business also had a positive relationship with their working behavior having a significance rank of 0.05 by using the Pearson's Product Moment Correlation result of 0.74; and 4) the working motivation of the personnel in the tourism business also had a positive relationship with their working behavior having a significance rank of 0.05 by using the Pearson's Product Moment Correlation result of 0.79.
\end{abstract}

Keywords: Motivation; Working behavior; Frontier tourism

\section{INTRODUCTION}

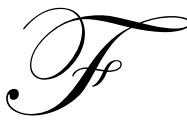

or the past decade, tourism has been a major source of revenue for Thailand. People consider tourism to be one of life's necessities. After working hard, they choose to go to a nice place, have new experiences, and get some needed relaxation and tourism healthcare. Tourism is booming because many people join businesses hoping to be able to travel after some time.

The Travel Guide Agency Act of 1992 determined that tour operators must have permission to do business in order to control product seine and service for customer satisfaction. Nowadays, there are a lot of regulations to govern tourism and hotel management. Because of the increase in tourism, generic standards of tourism have been established; i.e., a guide must be certified in order to work. These regulations encourage people to try to improve their skills in order to get higher pay, which is the major way to motivate people to join this industry. When the pay matches the requirements of the workers' tasks, the result will be higher efficiency (Watcharayoo, 1994). 
Work satisfaction is the motivation for working, and it is this motivation that leads people to perform their tasks successfully. Motivation is therefore very important in management. Positive motivation can lead to positive working behavior. Kaewprom (2005) studied about "Impact factors for working behavior of teachers in schools in the $3^{\text {rd }}$ area of education in Ubonratchathani". They determined that the aspects of the work, attitude, success, policy and responsibility had a positive relationship with the working behavior of government officials in that area. Also, Khampen (2001) who studied the motivation in working of bank officers (Case Study of Kungsri Ayuthaya Bank, Chaingmai) and found that most officers agreed that motivation policies, like having a good working manual, helped them to work very well.

The above reasons helped to influence the researcher's interest in a study about motivation and work behavior in business tourism and to find a relationship between them. This led to the decision to study Thai-Laos tourism, which is presently popular at the fixed borders in Nongkhai, Mukdahan, and Ubonratchathani. The results will be used as criteria for managing, improving, and revising the motivational factors necessary for working in the tourism business with a high amount of efficiency.

\section{OBJECTIVE OF THIS STUDY}

1. To study the motivation for working and working behavior in the frontier tourism business at the Thai-Laos border.

2. To compare the working behavior between travel agencies and hotel businesses.

3. To study the relationship between working motivation and working behavior in tourism businesses.

\section{HYPOTHESIS}

1. The working behavior of personnel in the travel agency and hotel businesses is different.

2. The working motivation and working behavior of personnel in the travel agencies is related.

3. The working motivation and working behavior of personnel in the hotel business is related.

4. The working motivation and working behavior of personnel in the tourism business is related.

\section{SCOPE OF THIS STUDY}

This research is about the study of motivation and working behavior of those working in tourism at the Thai-Laos border, the scope of which the author defines below:

Scope of area - area of tourism at the Thai-Laos border separated into hotels and travel agencies in the three provinces of Nongkhai, Mukdahan and Ubonratchathani

Scope of details - details of the study consisting of motivation and working behavior

Scope of population - includes management and operation officials in tourism in the three provinces of Nongkhai, Mukdahan and Ubonratchathani

Scope of time - from July 2008 to June 2009

\section{GLOSSARY}

Motivation - the process of reaction to the needs of a person which motivates that person to do whatever is necessary to achieve his/her objective

Working behavior - methodology of developing a positive attitude, sense of success, policy of management, sense of responsibility, and positive behavior related to that work

Travel agency - agency that has the license of a legal tourism company 
Hotel business - business accommodation that has the license of a legal hotel company and is a member of the Thai Hotel Association

Tourism business - tourism business that has the license of a legal tourism company

Frontier tourism - all activities established to serve tourists at the Thai-Laos border

\section{FRAMEWORK}

The definition of the framework of the study "Motivation and Working Behavior in Frontier Tourism Business of Thailand-Laos" is shown in Chart 1.

Chart 1: Framework of "Motivation and Working Behavior in Frontier Tourism Business of Thailand-Laos"

\begin{tabular}{||rl||}
\hline \multicolumn{2}{|c|}{ Motivation for working } \\
1. & Success of work \\
2. & $\begin{array}{l}\text { Assistance from competent } \\
\text { colleagues due to a good work } \\
\text { relationship }\end{array}$ \\
3. & Aspects of work \\
4. & Responsibilities at work \\
5. & Progress of work \\
6. & Stability of work \\
7. & Salary and social status \\
8. & Policy \\
9. & Work environment \\
10. & Good governance \\
11. & Relationship with colleagues \\
& and supervisors \\
\hline
\end{tabular}

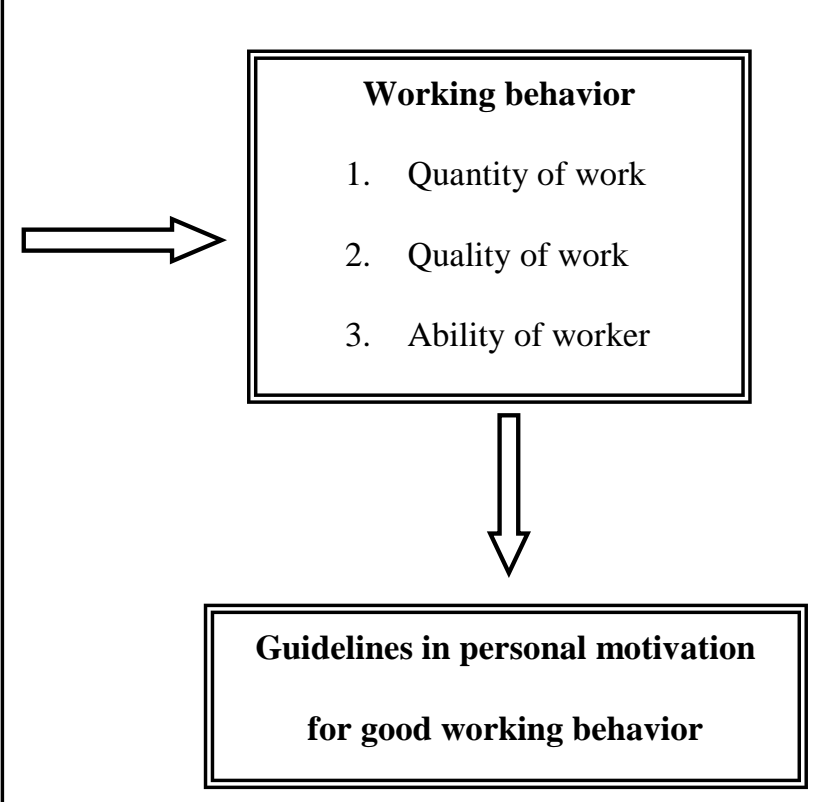

\section{METHOD}

This study was a research survey involving the motivation and working behavior in tourism at the ThaiLaos border that was done in order to find a way to better manage and improve the working behavior in tourism. The results will be used to develop better methods of motivating those working in the tourism industry. 


\section{SAMPLE GROUP OF THE STUDY}

Random research tests were done involving management and operation officials of tourism businesses at the Thai-Laos borders of three provinces; i.e., Nongkhai, Ubonratchathani and Mukdahan. This was done at hotel businesses and travel agencies that had legal company licenses and hotel businesses that were members of the Thai Hotel Association. The group consisted of six hotels and ten travel agencies as shown in Table 1:

Table 1: Sample Group of the Study

\begin{tabular}{l|l}
\hline Hotel Businesses & Tourism Businesses \\
\hline Kangsapeu Riverside Hotel, Ubonratchathani. & Sakda Travel World, Ubonratchathani. \\
Ubon International Hotel, Ubonratchathani. & Ubon-Surachai Travel Center, Ubonratchathani. \\
Ploy Palez Hotel, Mukdahan. & Nevada Grand Travel, Ubonratchathani. \\
Mukdahan Grand Hotel, Mukdahan. & Mukdahan International Tourim, Mukdahan \\
Nongkhai Grand Hotel, Nongkhai. & Paphavadee Tourism, Mukdahan \\
Royal Mae-Khong Nongkhai, Nongkhai. & Dimon Inter Tour, Nongkhai \\
& Parichat Tour, Nongkhai \\
& Kantana Tour, Nongkhai \\
\hline
\end{tabular}

\section{VARIABLES OF THE STUDY}

1. Independent variable: working motivation

2. Dependent variable: working behavior

\section{TECHNIQUE OF THIS STUDY}

The working motivation test was based on the theory of Maslow (1954), the need to achieve theory (Mcclelland \& Akison, cited in Santiwong, 1990), and the theory of motivation by Herzberg (cited in Santiwong, 1990). The test consisted of 11 items: 1) success of work, 2) assistance from colleagues, 3) job description, 4) responsibilities at work, 5) progress of work, 6) stability of work, 7) compensation and social status, 8) policies of organization, 9) work environment, 10) management system of organization, and 11) relationship with colleagues and supervisors. All 11 items were used with a choice of positive or negative responses, and 43 questions were applied using the Likert scale as a research test.

Positive questions involved success of work, assistance from colleagues, job description, responsibilities at work, progress of work, and stability of work. Negative questions included compensation and social status, policies of organization, work environment, management system of organization, and relationship with work mates and supervisors.

The working behavior test concerned questions on working behavior, work satisfaction, and the relationship with work mates and supervisors.

\section{INFORMATION OF ANALYSIS AND STATISTICS}

The researcher analyzed the information by using the SPSS for Windows program and presented it by information analysis explanation. The statistics of the information analysis are:

1. Percentage statistic explains the characteristics of demography (sex, age, status, education, career and income per month)

2. Mean and standard deviation: SD

3. Test of hypothesis used a t-test to test differences between the average of the two independent groups at a significance level of 0.05 .

4. Correlation analysis in the relationship level test used a coefficient of correlation. 


\section{RESULTS}

Personnel in the tourism business consisted of $42.1 \%$ males and $57.9 \%$ females. The ages ranged as follows: 15-25 years old (15.0\%), 26-35 years old (53.6\%), and 36-45 years old (26.4\%). The educational levels of the sample group were high school diploma or equivalent (28.6\%), associate's degree or equivalent (27.9\%), and bachelor's degree $(27.9 \%)$.

Most of the personnel in the tourism business had a working motivation in the moderate range (57.9\%); the others were in the high range (42.1\%). Concerning success of the work, the most significant impact in this area was when colleagues gave moral support. Other factors were position change, salary, and work performance measured by the amount of work responsibility given.

The biggest impact from colleagues was due to their competence and their working relationship with the respondents of the sample group. The respondents were willing to receive knowledge from their colleagues and they trusted them in things involving important work.

The most significant impact concerning the aspect of the work was in personal development and the career path of the work. Another factor was their personal satisfaction and happiness with their work. The biggest impact on responsibility for work involved the respondents' being fully able to fulfill their responsibilities and being on time for work. The other part was company assurance of their importance.

The most relevant impact on progress-in-work was the support from the company for opportunities to make personal improvement of skills and also company support of continuing education. The greatest impact on stability of work was the respondents' perception on the stability of the company and also whether the company only fired their staff for serious infractions.

The most significant impact from salary and social status was whether the pay received matched their skills and whether they could get more money for working at higher levels. Another factor was receiving appropriate pay for their knowledge and ability.

The biggest impact in policy was company policy that fit into the current economy and matched the personal goals of the respondents, in addition to goals that were directed toward their needs. The greatest impact concerning work environment was location and the facilities at the workplace that promoted better working conditions, followed by the company having appropriate materials and modern office equipment.

The most significant impact in good governance was established company rules and a charter to govern work. Next was whether the company offered opportunities for work advancement and had a work manual for reference. The most important impact concerning the relationship with colleagues and supervisors was cooperation between colleagues, followed by respondents having a family-type relationship with their colleagues.

Finally, in the area of working behavior, it was found that the personnel in the tourism business thought they had work quantities in the moderate range $(45 \%)$. For overall of work image qualities, they were in the high range $(42.9 \%)$. Therefore, the respondents considered the resources worthy by having an average in the highest range and also being able to finish the work by themselves. Completing their workload with minimum errors was also a factor. Part of the overall image ability revealed that they were in the high range. The respondents had an average range for morality and were in the high range for responsibility for work, sensibility, framework, teamwork, expertise in service, and strategic management.

Respondents from the tourism business had a relationship with the organization in the moderate range and if someone criticized their organization, they rose up into the high rate. 


\section{RESULTS OF HYPOTHESIS}

\section{The $1^{\text {st }}$ Hypothesis}

Working behavior of the personnel in travel agencies and the hotel business would be different. The result of this hypothesis found that the working behavior of people in the travel agency and hotel businesses was not different, having a significance rank of 0.05 .

\section{The $2^{\text {nd }}$ Hypothesis}

The working motivation of the personnel in travel agencies would have a positive impact on their working behavior. The results of the hypothesis found that the working motivation of the personnel in travel agencies had a positive impact on their working behavior having a significance rank of 0.05 by using the Pearson's Product Moment Correlation result of 0.69 .

\section{The $3^{\text {rd }}$ Hypothesis}

The working motivation of the personnel in the hotel business would have a positive effect on their working behavior. The working motivation of the personnel in the hotel business had a positive effect on their working behavior having a significance rank of 0.05 by using the Pearson's Product Moment Correlation result of 0.74 .

\section{The $4^{\text {th }}$ Hypothesis}

The working motivation of the personnel in the tourism business would have a positive affect on their working behavior. The working motivation of the personnel in the tourism business had a positive affect on their working behavior having a significance rank of 0.05 by using the Pearson's Product Moment Correlation result of 0.79 .

\section{CONCLUSION}

From the analysis, it was found that the most significant impacts to success of the work were when successful colleagues cheered up the respondents, and when there was a change in position or pay. When colleagues commended them for their performance, it motivated them to work better and promoted better behavior. When they were promoted to a new position that improved their social status, it raised their level of esteem. This matches with the theories of Maslow, Herzberg and EERG and Alderfer Maslow stating that motivation from colleagues stimulates competence, a good work relationship, and satisfies the social needs.

Concerning the aspects of the work, Herzberg suggested that motivation arose from personal development and a definite career path in the work, including the opportunity to develop in required areas, opportunities for promotion, and opportunities for continued education, which affected job satisfaction". This is in agreement with the research findings.

Concerning stability of work, the theory of Herzberg states that motivation arises from knowledge that the company will only terminate staff for serious infractions. Concerning pay and social status, motivation arises from people being paid commensurate with their skills and feeling assured that they will receive more when their work improves to a higher level. This agrees with the theory of Herzberg who said that salary and salary upgrades led to the satisfaction of personal and better working behavior.

Regarding policy, motivation arises from company policy that fits into current economies and that matches with personal goals, which produces better working behavior.

As far as work environment, the location and facilities of the workplace affected better work. The theory of Herzberg says that factors of the heart will pacify and help remove dissatisfaction in the workplace and things, such as workplace location, materials and modern office equipment, are important. 
Good governance involves establishing regulations, having a reference work manual, and providing forums for open discussion which can lead to better job satisfaction. This is supported by the research of Khampen who studied the motivation in working of bank officers: case study of Kungsri Ayuthaya Bank, Chaingmai; i.e., if the bank had a good work manual, it helped promote better performance.

Concerning relationships with colleagues and supervisors, motivation arises from cooperation of colleagues and a family-type atmosphere in the workplace. Moreover, direct-indirect communication helps further promote this topic.

In the area of working behavior of personnel in the tourism business, they felt that their quantity of work was in the middle level. For quality of work, the focus was on how to utilize resources, how to finish their workload by themselves and to do their job with a minimum amount of errors.

Ethics, responsibility, sensibility, framework, expertise in service and strategic management all help promote low conflict and is based on what Davis said: "When people are older, their work behavior will be better because they have more experience. The pride and happiness from talking about one's workplace, satisfaction with pay, having a good work policy, and having a good work manual can help too.

The assumption was that working behavior in travel agencies and the hotel business was not different because both of them are management-oriented with most of the work produced by serving. The motivation for working of the personnel in travel agencies is related to their positive working behavior, and the motivation for working of the personnel in the hotel business is also related to their positive working behavior. The motivation for working of the personnel in the tourism business is the same - related to their positive working behavior.

This was based on the research of Rohitsatian who studied motivation and working behavior of the head of flight attendants on an airplane (Case Study of Thai Airways) and found that their motivation was in the medium range for achieving, work relationships, and power. Their total motivation had a positive impact on their working behavior.

\section{SUGGESTIONS FOR ADDITIONAL STUDY}

1. This research was done to find the relationship of work motivation on behavior in Frontier tourism at ThaiLaos borders in order to improve the management style in tourism. Additional research should be done to identify more organizations in each area so that there can be an increase in services provided to tourists.

2. Subsequent research should study the meaning of communication between people in business in order to build a network for exchange of knowledge to solve problems regarding the potential development of tourism in the future.

\section{AUTHOR INFORMATION}

Dr.Thirachaya Maneenetr is an Assistant Professor and also a Head of the Department of Tourism at the Faculty of Management Science, Khon Kaen University, Thailand. She received her Ph.D. in Architectural Heritage Management and Tourism from Silpakorn University, Thailand. She has authored a public paper on tourism management and cultural tourism.

\section{REFERENCES}

1. Bunnak, M. 1994. Statistic for decision. Bangkok: Chulalongkorn University.

2. Connellan, T.K. 1978. How to Improve Human Performance: Behaviorism in Business and Industry. New York: Harper \& Row.

3. Cronbach, L.J. 1972. Essential of Psychological Testing ( $3^{\text {rd }}$ ed.). New York: Harper and Row Publisher.

4. Davis, K. 1977. Human Behavior at Work: Organizational Behavior. New Delhi: Tata McGraw - Hill.

5. Jaturongkhakul, A. 2002. Customer behavior. Bangkok: Thammasat University.

6. Kagen, J. \& Havemann, E. 1968. Psychology: An Introduction. New York: Harcourt, Brace \& World. 
7. Keawprom, R. 2005. Impact factors for working behavior of teachers in schools in the $3^{\text {rd }}$ area of education in Ubonratchathani. Master of Education thesis, Education test and evaluation department: Rajapat Ubolrajathani University.

8. Khampen, W. 2001. Motivation in working of bank officers: case study of Kungsri Ayuthaya Bank, Chaingmai. Chaingmai: Chaingmai University.

9. Khampolhang, T. 2002. Influencing factors for working behavior in case study investigation of police, Investigate department of Capital police 1-9, Capital police. Master of Science thesis, Industrial philosophy department, Graduate student: Kasetsat University.

10. Laksita, P. 1993. Analysis of customer behavior. Bangkok: Edison press product.

11. Maslow, A.H. 1954. Motivation and Personality. New York: Harper \& Rov.

12. Meungman, T. \& Suwan, S. 1997. Organization behavior. Bangkok: Thaiwatthanaphanit.

13. Navikarn, S. 2002. Organization behavior. Bangkok: Thai Letter.

14. Phan-arun, A. 2003. Factors for working behavior of tourist guides having to register in Bangkok, at Tourism Authority Thailand. Master of Business Administration thesis, Management department, Graduate student: Srinakarinwiroj University.

15. $\quad$ Porter,L.W. \& Bigley, G.A. 2004. Motivation and Work Behavior. New York: McGraw - Hill.

16. Rohisatian, P. 1998. Motivation and working behavior of the head of flight attendance on an airplane: case study of Thai Airways. Master of Science thesis, Industrial philosophy department, Graduate student: Kasetsat University.

17. Sangsorn, C. 2007. Relationship between hopelessness in working and working behavior of officers, case study of a spare cars production factory. Master of Arts thesis, Industrial philosophy and organization department, Graduate student: Prajomkloa Tecnology Pranakornneu Institute University.

18. Santiwong, T. 1990. Organization and administration. Bangkok: Thaiwatthanaphanit.

19. Santiwong, T. 1994. Customer behavior marketing. Bangkok: Thaiwatthanaphanit.

20. Santiwong, T. 1997. Organization and modern management of globalization. Bangkok: Thaiwatthanaphanit.

21. Schiffman, L. G. \& Leslie, L. K. 1994. Consumer behavior (5 $5^{\text {th }} e d$.). Englewood Cliffs, New Jersey: Prentice - Hall, Inc.

22. Sinthupun, P. 2003. Motivation in working and improving the personality for the best accountant in civil service offices and private offices, in Mueng Lampoon district. Master of Science independent study, Industrial philosophy and organization department, Graduate student: Chiangmai University.

23. Srisa-ad, B. 1998. Statistic method for research ( $2^{\text {nd }}$ ed.). Bangkok: Suweeriyasan.

24. Thammacharen, Y \& Group. 2001. Customer behavior 1-8 factor. Nonthaburee: Sukhothaithammathiraj University.

25. Thupprom, P. 2007. Relationship between cultural organization perception, relationships for organization and working behavior of officers, TOT. Master of Science thesis, Industrial philosophy department, Graduate student: Kasetsat University.

26. Wanitbuncha, K. 2001. Statistics analysis: Statistics for decisions. Bangkok: Statistic department, Faculty of Commercial and Accounting, Chulalongkorn University.

27. Watcharayoo, P. 1994. Motivation in working. Bangkok: Odian store.

28. Wongmontha, S. 1999. Customer behavior analysis. Bangkok: Theerafilm \& Sitax.

29. Wongratana, C. 1998. Statistics techniques for research. Bangkok: ThepnaramitKanphim.

30. White, D.D. 1989. Organization Behavior. New York: Jimone \& Schaster, Inc. 